\title{
As Fachas de Vilelos. Antropoloxía dunha festa do lume
}

Fachas of Vilelos. An Anthropology of a fire feast

http://dx.doi.org//10.15304/gall.38.6296

Rosa Brañas Abad

Grupo de Estudos de Arqueoloxía, Antigüidade e Territorio (GEAAT), UVigo

rbranas@uvigo.es

\section{Resume}

Na véspera da festa parroquial de San Martiño de Vilelos (O Saviñao, Lugo) os veciños celebran o Fulión, que consiste en subir ao castro máis próximo grandes fachas e tirar dende alí grande cantidade de fogos artificiais. Neste artigo recollemos a etnografía do Fulión de Vilelos e propoñemos unha interpretación sobre o seu posible significado.

Palabras clave: Vilelos, Festa do lume, Fachas, Vésperas, Agucios.

\begin{abstract}
On the eve of the parish feast of St. Martiño de Vilelos (O Saviñao, Lugo) neighbors celebrate the Fulión, wich consists of taking fachas (big torches) up the nearest hillfort and throw from there lots of fireworks. In this article we collect the ethnography of the feast of Vilelos and propose an interpretation of its possible meaning.
\end{abstract}

Keywords: Fire feast, Torches, Fulión, Vespers, Asphodel. 


\section{Presentación $^{1}$}

As vésperas da celebración da festa parroquial da Virxe das Angustias en San Martiño de Vilelos (O Saviñao, Lugo) é unha de tantas festas populares galegas protagonizadas polo lume e estreitamente relacionadas cun castro prehistórico. Celébrase a finais do verán, na última semana de setembro.

Nese venres anterior á festa relixiosa, os organizadores ou ramistas xa teñen preparada a pólvora para a "Festa das Fachas" (tradicionalmente chamada Fulión), e os veciños as súas fachas de agucios (denominación dialectal das abrótegas, Asphodelus albus) para queimalas no castro, segundo un ritual fixado pola tradición, que algo cambiou no fundamental dende que se recorda.

O traballo de investigación de campo que sirve de base a este estudo desenvolveuse no ano 2009 durante a mesma Festa das Fachas e en días anteriores, cando entrevistamos á veciñanza e documentamos a elaboración das fachas por parte dos membros da Asociación de Veciños de San Martiño de Vilelos, o grupo veciñal comprometido coa conservación desta festa peculiar tan merecedora de preservarse e coñecerse.

\section{UN ENFOQUE HISTÓRICO}

O presente estudo céntrase especialmente no coñecemento da festa no pasado, tan atrás no tempo como poden lembrar os seus protagonistas. Trátase, por tanto, máis ben dun estudo de antropoloxía histórica, no que a fonte de documentación principal é a enquisa de campo, na que se recolle tanto a lembranza persoal como o coñecemento adquirido por transmisión oral. Enfocando o noso interese nese pasado recente, que non remontaría moito atrás da década dos anos 1950, o contexto social, económico, político e cultural no que se insire a festa de Vilelos compréndese dentro do marco xeral da estrutura parroquial galega ben estudada e descrita por Carmelo Lisón na súa Antropología Cultural de Galicia (Lisón 2004), á que nos remitimos para comprendermos o contexto familiar e social no que se insiren os testemuños recollidos no traballo de campo.

\section{Historia escrita e Historia Recordada}

A parroquia de San Martiño de Vilelos, no concello lucense do Saviñao, está integrada actualmente por 10 lugares: A Besta, Lamagrande, O Quintairo, Pedras, San Martiño, Santa Cruz, A Santa Mariña de Vilelos, Susmil, Vilaseco e Vilelos. Moitos dos veciños destes lugares ou aldeas participaban na Festa das Fachas de maneira activa, nas quen-

1 O traballo de campo do que resulta estre traballo, desenvolvido no ano 2009, foi subvencionado pola Deputación Provincial de Lugo. O mesmo non tería sido posible sen a participación da miña compañeira Carme Pernas Bermúdez, responsable conxuntamente comigo do traballo de enquisa, rexistro e transcrición dos informes empregádos, sendo da miña única responsabilidade a interpretación dos datos aquí ofrecida. Aproveito para manifestar a miña gratitude a todos os veciños e veciñas de Vilelos que amablemente se prestaron a compartir connosco as súas lembranzas e experiencias, así como aos membros da Asociación de Veciños, especialmente a Tania Mirás, Verónica Cidre e José López, os mellores informantes e anfitrións cos que se poida contar. 
das dos ramistas, na hospedaxe dos músicos, na elaboración e queima das fachas, etc., é dicir, todo iso polo que se tiña plena conciencia dunha festa parroquial.

Os primeiros datos históricos que se nos transmiten relativos especificamente á festa de Vilelos proveñen dun artigo de LÓPEZ CUEVILLAS e FRAGUAS FRAGUAS (1953: 286). Trátase dun comentario sobre o Castro da Besta integrado no catálogo dos castros do Saviñao. Sen embargo, a noticia parece cargada de erros e imprecisións, que sinalamos en negriña:

"El recinto interior posee en la superficie gran cantidad de piedras sueltas que suponemos habrán sido de casas o del parapeto. En esta parte se celebra el folión de la fiesta de San Juan, donde se enciende una gran hoguera que dura toda la noche y los jóvenes llevan grandes haces de paja en la mano, que encienden, y con ellos encendidos recorren el castro durante varias horas mientras dura el folión".

Bastante máis recente, e tamén máis atinada, é a descrición que nos ofrece VÁZQUEZ RODRÍGUEZ (1998: 263-266) nun artigo no que se trata de modo xeral o tema dos fulións/folións galegos, a maioría deles completamente desaparecidos, e logo máis polo miúdo os da Ribeira Sacra, precisamente os que gozan hoxe en día de vixencia, e aínda de grande vitalidade: ademais do de Vilelos (VÁZQUEZ RODRÍGUEZ 1998: 263-266), o de Castelo (Taboada, Lugo) e Castro Caldelas (Ourense).

As orixes da festa, como adoita dicirse, remonta a tempos inmemoriais, porque, efectivamente, non hai recordo dos seus comezos. Todos os nosos informantes concordan en que os máis vellos dicían recordala de toda a vida e que o mesmo lles escoitaran aos seus maiores. "Era unha cousa que había de sempre nesta parroquia, recórdoo eu e recordábano os meus antepasados" (B.F., 80 años)

A idea de que o fulión se celebrou ininterrompidamente dende que se recorda é un dato controvertido, posto que, aínda que algúns o afirman con toda convicción, outros dubidan, como se tivesen o traslumbre de que nalgún momento fora suspendido (pero sen saberen precisar cando nin as posibles causas; como moito, especúlase con que durante a Guerra Civil seguramente non se celebraría: “Daquelas non habería folión...”).

En todo caso, unha carta enviada pola comisión de festas e a Asociación San Martiño ao Delegado de Cultura de Lugo no ano 2003, informa acerca desa falta de continuidade: ao tempo que se describe e se solicita axuda institucional para a recuperación da festa tradicional, tamén se di que se viña celebrando con "algunos vacíos"2.

O máis vello dos nosos informantes tiña daquela 92 anos, pero a media de idade dos máis maiores apenas superaba os 70, polo que a historia reconstruída a partir dos seus testemuños non pode remontar máis atrás das décadas 30-40 do pasado século. Pero tampouco non é posible afinar demasiado nas datas, posto que a memoria é fráxil e as lembranzas se mesturan confusamente na mente dos nosos protagonistas. Isto débese, entre outros factores habituais na transmisión oral (cf. VANSINA 1965: 40), aos profundos cambios acontecidos ao longo do século no desenvolvemento do fulión, coa

2 Aínda que nesta carta se menciona un documento do século XVIII que falaba do fulión, non puidemos localizalo. 
incorporación de novas actividades e incluso diferentes tipos de participantes, ao longo, especialmente, do último cuarto do século XX, cando os cambios eran tan fugaces que a maioría non chegaron a callar entre os actos festivos anualmente repetidos.

Así, tras unha curta tempada de certa decadencia, a festa rexurdiría a finais dos anos 70, pero cun carácter que a carta anteriormente mencionada critica ao referirse a "realizacións non de acordo coa tradición". En efecto, parece ser que entre finais dos 70 e inicios dos 80 comezou a promocionarse a festa coa denominación de "Festa Celta", que se celebraron concursos de gaitas e se introduciron outros cambios cos que a comisión de festas de 2003 se manifestaba abertamente contraria. Parece coincidir con esta época o testemuño dun veciño segundo o cal se trasladara toda a festa ao castro (onde se montaban chigres e se organizaban "pancetadas"), cousa completamente en desacordo coa tradición.

Posto que non podemos remontarnos moito máis atrás no tempo para coñecer mellor esta celebración nun pasado máis afastado, nin recorrer a etnografías ou relatos dende unha perspectiva externa á comunidade do noso interese, senón só servirnos dos testemuños orais dos nosos informantes, vexamos que podemos coñecer da historia da festa a partir das súas lembranzas.

\section{Descrición do Fulión. Preparativos. Organización e Celebración}

A facha, como o seu nome indica, non é máis que un feixe de vexetais destinado á queima, xeralmente para a iluminación e de grandes dimensións. En Vilelos o vexetal empregado para este fin é o asfódelo (Asphodelus albus), que na zona (e outros lugares do sur de Lugo), recibe a denominación dialectal de agucio (noutros lugares mellor coñecido como abrótega, abrotea, etc.), unha planta liliácea cun talo semellante a un xunco (fig. 1).

A preparación da facha pasa pola recollida do agucio dous ou tres días antes da festa e o seu posterior secado, para asegurar unha boa combustión. Nos últimos anos, a súa recollida no monte era fomentada entre a cativada e a mocidade da parroquia por parte da Asociación de Veciños de Vilelos, quen os mobilizaba moi eficazmente como parte dunha actividade colaborativa, lúdica e, por tanto,

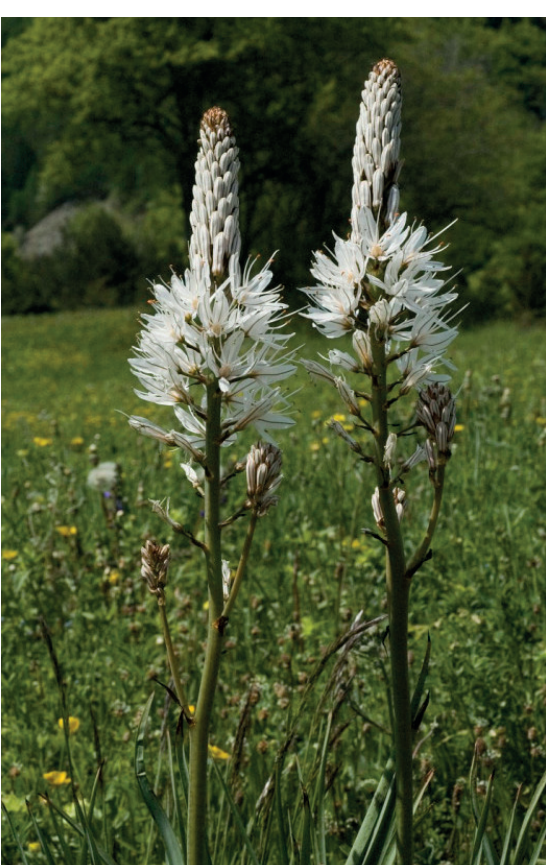

Figura 1. Agucio (Asphodelus albus). profundamente motivadora.

Cóntase que noutrora dedicaban entre " 7 ou 8 sestas" a buscar agucios, indo por eles moi lonxe, ata a ponte de Chantada ou Lagares. Comezaban a apañalos logo do mes de agosto, cando a planta xa estaba seca.

Para a preparación das fachas, os agucios secos vanse separando por feixes e cada feixe vaise superpoñendo ao anterior (a media altura do talo, aproximadamente) e atán- 
dose cun cordello, ata acadar a altura desexada. As máis altas necesitaban unha póla de carballo a xeito de poste, para non se dobraren.

Sen embargo, dende o pasado, hai algúns detalles na elaboración das fachas e no modo de participación dos veciños e veciñas que cambiaron substancialmente. Para empezar, na festa das fachas só participaban activamente os homes, especialmente os mozos e os pequenos. Eles apañaban os agucios, elaboraban as fachas e carretábanas, mentres que as mulleres, aínda que podían axudar a facelas, só actuaban como comparsas durante a celebración da festa: "Daquelas as mulleres non iban coas fachas, eso era todo cousas dos mozos, dos mozos do pueblo. De fóra do pueblo xa tampouco iban tanto, era para os de eiquí da parroquia. Pero agora van de fóra e todo [...] As mulleres era pa' divertirse e bailar" (B.F).

Hoxe en día interveñen todos indistintamente, posto que, ao percibirse a festa como simple divertimento, animan a todos os rapaces e rapazas a que fagan a súa propia facha, axudándolles nese labor. Aínda máis, as compoñentes máis activas da asociación de veciños é un grupo de mozas, quen non só aprenderon a facer fachas e animan aos máis novos a interviren nos preparativos ${ }^{3}$, senón que tamén se senten orgullosas de axudar a revitalizala coa súa participación e se mostran moi interesadas por coñecer as tradicións locais e certos modos de facer antigos. O único que non están dispostas a conservar, obviamente, é o vello costume de excluír ás mulleres, a pesar das reticencias das súas propias avoas. "De feito -comenta T.M.L., muller, 28 anos- a miña abuela cada vez que me ve salir aos agucios, ponse dos nervios. Pero... é o que hai! [conta entre risas e as das súas compañeiras]”.

Debido á súa propia curiosidade e interese, son plenamente conscientes de que reproducen cambios recentes no modo tradicional de facer as fachas. Cóntannos que elas amarran as fachas con cordellos cando saben que o tradicional era empregar "vimias" (ou vimbias) ou tamén xestas, que non usan porque son máis difíciles de apañar e tamén de manexar. Tamén contan que antano as fachas podían facerse con ramas de carballo, esmagándolles as puntas, o que recibía o nome de "coias": "Esmagábanas ben p’a que arderan e duraran moitísimo máis. Como non había luz pública, era o que utilizaban [...] Ás veces facíanas sólo con ramas de carballo e a veces metíanas no medio aos agucios”.

Veciños máis vellos confirmaron este dato. Contan que adoitaba botarse man das pólas de carballo cando rareaban os agucios, pois tamén abundaban os rapaces que se dedicaban a apañalos (entre 20 ou 30, total de fachas que, polo que contan, se xuntaban na festa). Estas pólas debían apañarse con máis antelación, un ou dous meses antes, asollalas ou secalas ao forno, mazalas e poñelas outra volta a secar, para axiña facer unha facha con 4 delas, aproximadamente. Como estas tardaban máis tempo en arder, empregábanse para alumar o campo da festa pola noite.

As nosas informantes coñecían tamén outro xeito de facer fachas diferentes do que empregaban decote. No canto de superpoñer ao chou os feixes de agucios, podíase facer máis ordenadamente, de maneira que as novas capas tapasen os cabos dos agucios das

3 Son elas as que reúnen aos nenos e nenas para apañar os agucios e os convocan para elaboraren as fachas o día antes do fulión (ese ano fixeron un total de 14 entre todos). 
capas inferiores e os cabos con flor quedasen máis á vista. A este modo refírese outro veciño máis vello ao describir como se facían as fachas na súa mocidade: "Empezábase no fondo. Facíase un magote, despois íbase revestindo de agucios e, con vimbia, atabámolas. Porque, se se ataban con palla ou con xunca, ardían as correas e desfacíase a facha. E entonces atabámolas con vimbia. E autros pasábanlle a dúas vimbias ou tres, un alambre, pa'que foran queimándose pouco a pouco [...] O cu do agucio pa'baixo e a rama pa'riba" (J.J.L.L., 78 anos)

Considerando o feito (que logo comentaremos máis polo miúdo) de que as diferentes fachas competían por un premio que valoraba especialmente o tempo que duraban acesas, tamén se trampeaban para conseguir que tardasen máis en consumirse: engadíaselles palla ou xesta seca polo medio, pero isto considerábase trampullada e penalizábase no reparto dos premios.

Preparadas as fachas na "véspera das Vésperas" da festa parroquial, comezaba o Fulión na parroquia de Vilelos, que discorría como deseguida se describe.

Antigamente a organización da festa correspondía aos ramistas, grupos de veciños encargados da recadación e os preparativos, que facían quendas por pares de aldeas. Cada ano organizaban a festa representantes de dúas delas: Santa Mariña con Pedras, Lamagrande con Susmil, Quintairo con Vilaseco, Santa Cruz con A Besta, e Vilelos soa, porque era unha aldea grande. En 2009 ocupábase deste labor a Asociación de Veciños ${ }^{4}$.

Para correr cos gastos establecíase un escote entre todos os veciños, que moitas veces se negaban a pagar as cotas como non se garantise a celebración das vésperas da festa, o fulión. Naquel tempo a maioría contribuía con patacas, centeo ou trigo, o que era posible porque a malla fora recente, mentres que os máis pobres, polo que se conta, ofrecían uns poucos cartos ou simplemente o que podían. O escote recadábano os ramistas, quen reunían os produtos nunha casa e logo os vendían a mercadores que viñan dacabalo de máis alá de Chantada, da zona do Faro. Con eses cartos cubrían os gastos da festa. Disque tamén se doaba carne de porco, pola que logo se poxaba, pero esta tiña outro destino: "o dos lacós era aparte. Xa non iban pa' beneficio da festa, iba pa' beneficio do cura”.

A celebración das vésperas recibe noutros sitios galegos, ademais de en Vilelos, a mesma denominación de folión/fulión. Este termo, en sentido xenérico, refire o acto festivo de bourear, de meter moito balbordo. Para iso empréganse todo tipo de medios e instrumentos (cazolas, tambores, bombos), incluíndo o emprego da pólvora para tirar foguetes ${ }^{5}$.

En sentido máis estrito, o fulión é en realidade o termo que recibiu en Vilelos tradicionalmente a celebración destas vésperas, con todo o que inclúe, de maneira que, en rigor, esta é a súa denominación propia. De feito, é habitual entre os maiores referirse ás vésperas (que ninguén adoita mencionar con tal nome) como fulión ou tirar o fulión ${ }^{6}$.

4 O que se percibía como un cambio importante: "Agora métese calquera, pero antes era por pueblos".

5 Vázquez Rodríguez (1998) menciona numerosos paralelos fóra de Galicia, entre os que podemos contar as famosas Fallas valencianas.

6 Aínda que non tan lonxe, a menos de 20 km, en Castelo (Taboada), se celebra un folión con queima de fachas, tamén de longa tradición histórica, ningún veciño de Vilelos oíra nunca falar del no pasado. "En todo por eiquí non había ningún, ningún, ningún [folión con fachas]”. Este descoñecemento era, por certo, absolutamente recíproco, como tivemos ocasión de comprobar estudando tamén esta festa. 
O anuncio da festa con pólvora é o habitual en todos os folións, ao igual que subir ao castro, detalle que explican porque dende o seu cume poden divisarse todos os arredores e que, do mesmo modo, faise visible dende "todos os castros" (dende Escairón, Paradela, Chantada, Taboada e ata Monterroso)

Volvendo á festa na actualidade, o último venres de setembro (non coma sempre ${ }^{7}$ ), pola tardiña, van chegando ao campo da festa (na Cruz das Ánimas ou Cruceiro) todos os veciños, sexan homes, mulleres, anciáns ou mozos, moitos deles coas súas fachas (fig. 2). Antes de prendelas, a Asociación de Veciños ameniza a reunión cun convite xeral a unha torresmada (chámanlle "pancetada”), con acompañamento musical por parte de charangas e grupos de música tradicional. Eventos coma este, loxicamente, son innovacións recentes.

Logo de xuntarse todas as fachas na Cruz das Ánimas, posto que se compite polas máis longas e duradeiras, escóllense as máis altas para iluminar o baile cando comece. As "maiestras" ou maiores estéanse contra uns postes situados fronte ao campo da festa, deixando erguidas outras tantas (4 neste caso) máis pequenas no mesmo campo e con igual propósito. As opinións sobre as alturas alcanzadas polas máis altas que se recordan son tan dispares que apenas vale a pena aventurar unha dimensión concreta (chega a falarse de $25 \mathrm{~m}$, o que parece unha esaxeración). En calquera caso, cóntase que nunha ocasión fixeron unha tan extraordinariamente alta, que houbo que colocarlle unha roldana na cabeza para subir o fachuco

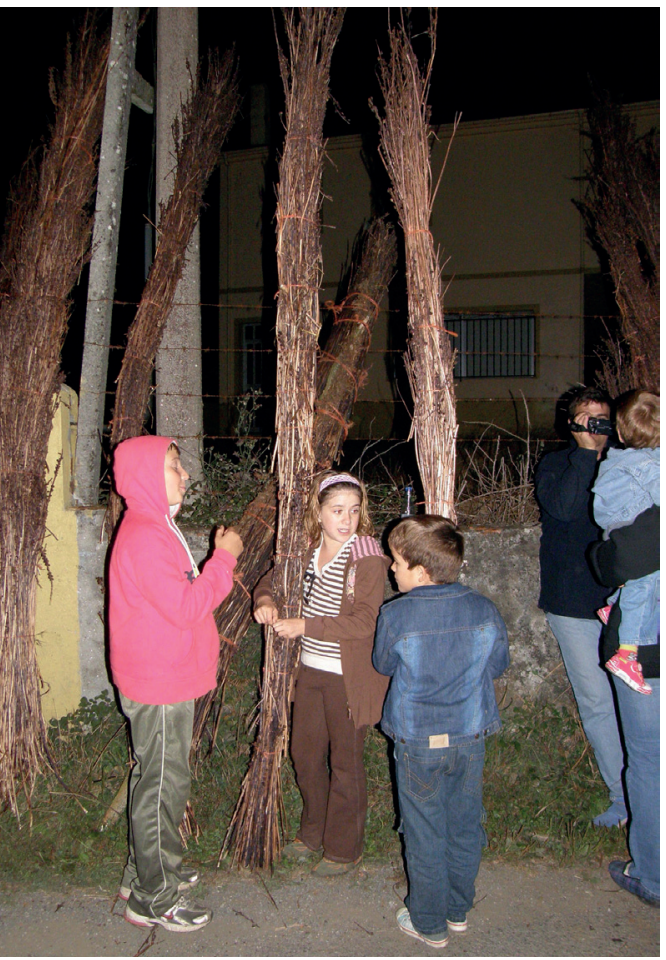

Figura 2

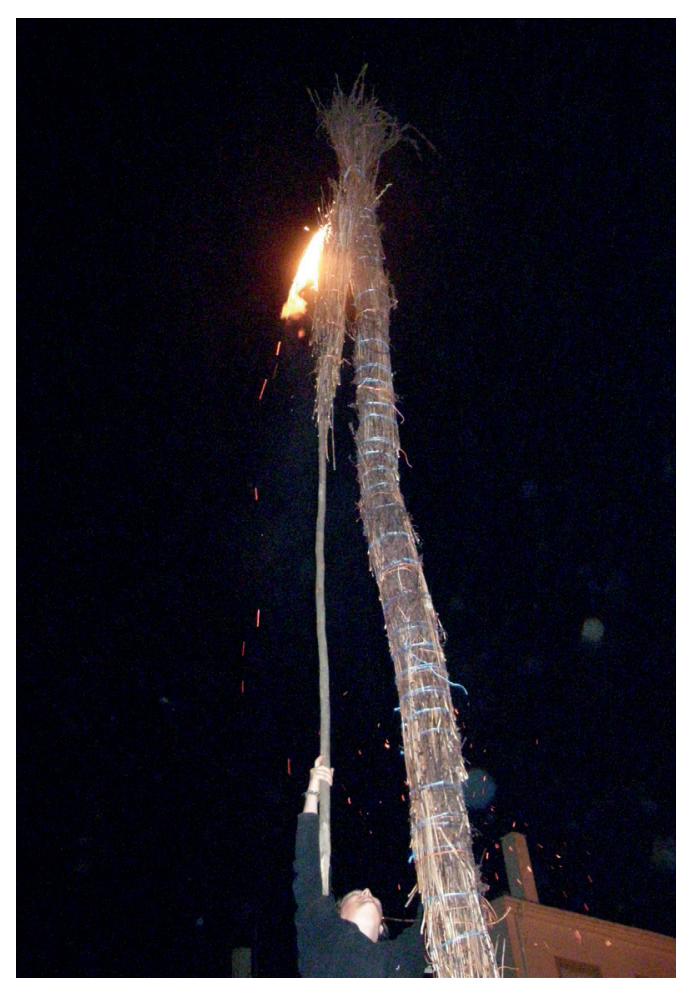

Figura 3 acendido destinado a prenderlle lume pola punta (isto faise xeralmente empregando unha pequena facha con mango moi longo, pero subíndose aos postes e con grande dificultade; fig. 3).

7 A data tamén padeceu cambios. Como a festa das Angustias se celebraba en domingo e luns, as vésperas caían en sábado. Agora, sen dúbida para favorecer a afluencia de xente, correuse un día cara atrás, me maneira que o fulión se celebra en venres. 
A parte destas fachas destinadas á iluminación do campo da festa, quen queira pode levar a súa. Daquela, pola media noite, vaise pasando o lume dunhas a outras (fig. 4) e, cada un coa súa en brazos (ou coa axuda doutros dous ou máis pares de brazos, dependendo da lonxitude), van subindo polo camiño que conduce ao Castro da Besta (fig. 5).

A comitiva de fachas, acompañada polos músicos, sobe en ringlei-

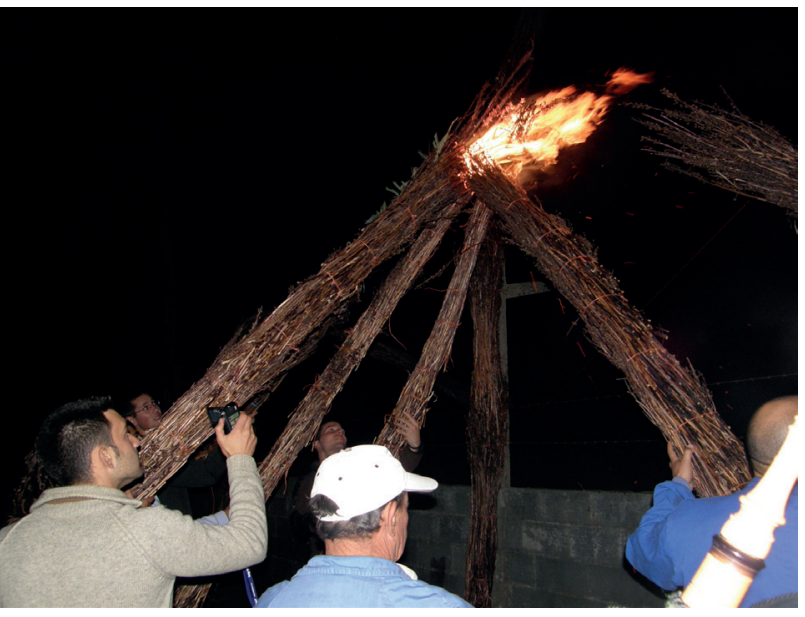

Figura 4 ra e, ao chegar á croa do castro, fai unha ronda completa, é dicir, percorre todo o perímetro do recinto. A pólvora anuncia o acontecemento en todo momento, reservándose o groso dos foguetes para o remate da ronda.

Despois de non demorarse moito no castro, a cabeceira da comitiva colle o camiño de baixada e retornan todos ao Cruceiro. Alí préndense as fachas do campo e as que baixan vanse concentrando nunha grande fogueira, ata que o lume esmorece. Daquela o baile xa irá ben adiantado na noite. Nestes momentos a comisión de festas invita a unha queima$\mathrm{da}^{8}$ e aproveitan para recompensar con cartos as mellores fachas (en categoría infantil e adultos). Nos últimos tempos interveñen grupos de música do país, moi diferentes das bandas ou das típicas orquestras que antano animaban o baile.

Os máis vellos aínda lembran os tradicionais cuartetos de gaitas (como o de Córneas), pero na memoria da maioría só permanece o recordo das bandas, presumindo de teren contratado as mellores e máis grandes do país. Ademais, era motivo de orgullo para este "pueblo do monte" que os forasteiros lles gabasen a calidade dos seus músicos. Disque

8 Como termo post quem da aparición da queimada nesta festa, temos o testemuño dun home duns 40 anos que asegura recordala de toda a vida, cousa que axiña lle replican os maiores. Este dato parece situarnos arredor dos anos 70. 
se comentaba: "Ises pegados ao monte que festas teñen e que bandas tran!. Tiñan moita fama porque sempre traían unhas bandas moi boas”; “...e despois dicían na festa, estaban uns homes que eu non os conocín: carallo pa' eses lugares do monte, vaia festa que tuveron!".

Esas bandas disque eran tan grandes que podían reunir ata 30 membros (que os veciños acollían nas súas casas), e tocaban dende a véspera, durante o fulión, ata o día da festa, cando facían pasarrúas por todas as aldeas da parroquia repartindo foguetes entre as casas e logo tocando na verbena.

Outrora todo pasaba de xeito bastante semellante, agás polas innovacións sinaladas e outros detalles que mencionaremos.

A xente reuníase con día no Cruceiro e, no solpor, subían todos ao castro, primeiro as fachas (entre 20 ou 30, ou incluso moitas máis, segundo as versións), logo os músicos e detrás o resto da xente. As leiras do castro, que algúns din que "sempre" se cultivaron con pan, patacas, millo ou herba, xa quedaran completamente limpas nestas datas (ou a maioría das veces: "Pero siempre estaba para aquela época.... Se estaba de patacas, pasábase igual, con menos dano, claro, non se iban pisar as patacas!")

Rodeábase o cumio do castro, logo botábase a pólvora e axiña baixaban para se xuntaren arredor do peto de ánimas ${ }^{9}$ que hai no Cruceiro, para dar comezo ao baile. Este non adoitaba prolongarse máis tarde da unha da madrugada: "Cando se apagaban as fachas, acabábase a verbena"; "Canto máis grande fora a facha, máis duraba a festa (...) Hoxe fanse máis pequenas por iso, porque da igual, como hai luz igual...” .

Os donos das fachas recibían diferentes premios segundo as épocas. En tempos recentes todos os concursantes recibían un foguete e o gañador dous ou tres. Máis antigamente os premios podían ser en cartos: dábanlles a cada un 2 reais por cada facha e 1 peseta polas grandes que quedaban embaixo. En calquera caso, M.F.R, de 92 anos, recorda que con 12 anos recibira un foguete pola súa facha (que non superaba os $2 \mathrm{~m}$ de longo e tampouco non resultara gañadora).

Logo das vésperas, celebrábase a festa parroquial típica, coas súas misas, merendas e verbenas, e ata unha corrida do galo para o remate.

\section{O FOlClore do Fulión}

“Cousas de vellos, de antiguo, que sei eu!" "eu neso non creo moito, pero malos ollos pode haber...".

A percepción xeneralizada por parte dos veciños e veciñas de Vilelos do seu fulión resúmese en que se trata dun evento simplemente festivo, dun divertimento. Malia os moitos intentos realizados por descubrir calquera outra causa, as respostas insistentemente revertían na mesma razón: isto faise por diversión.

9 Os petos de ánimas son monumentos pétreos que comezan a erixirse a partir do século XVIII, provistos de esmoleiro destinados a recadar cartos e pregarias polas ánimas do purgatorio. 
Pero, tras moito insistir, e sen por certo inducir ningunha resposta concreta, inesperadamente deuse unha resposta diferente, do tipo das que se reservan porque producen incomodidade, pois molesta dar a impresión de que se cae na superstición. De aí que, entre risas e expresións de escepticismo, se manifeste finalmente que os vellos dicían que se facía para escorrentar ás bruxas.

Pregunta: Algunha vez se dixo que o lume das fachas servira para algo, a parte de para pasalo ben?

F.M.: Pa' espanta-las bruxas!! [responde entre risas].

Pregunta: Si, é certo?

F.M.: Bueno, falábanse moitas cousas, pero... As fogueiras esas decían, "eh, que son contra as bruxas!"

E.G: E é certo, deso acórdome eu, que poñían as fachas pra..., p’a que non viñeran as bruxas.

Pregunta: Cóntenos deso.

F.M.: Deso non hai máis que decir!

E.G.: Hai pouco que contar, porque non se acorda un... Eu acórdome do que decía o abuelo e a abuela. Eu acórdome do que decían os viejos, pero... [...]

J. L.: E non podía ser tamén unha ofrenda, así..., hacia as vosas colleitas daquil ano, ou así? Non se marmuraba eso? ${ }^{10}$

F.M.: Non, eu eso nunca o oín.

E.G.: O das bruxas si, tiña moito auge. Deso acórdome, acórdome, das fachas e de que decía a abuela, a miña abuela, que en paz descanse, a Cabaza, que era... meiga, mui... mui santona, rezaba moito, tiña o rosario... Decía: Ide cidillo [sic] ide, ide cidillo ide, a ver se non veñen as bruxas.

Este feito semella estar tan arrecantado na memoria dos veciños, que incluso os máis vellos negan esta ou calquera outra razón especial para as fachas: "Non, eiquí eran para o día da festa, sólo se usaban na víspora da festa [...] arriba na’máis era tirar o folión pa' que o viran porque era un sitio que se ve dende tódolos lados. (...) Hoxe se cuadra non se ve tan ben polos árboles que hai”.

Aínda que si se lembran contos de bruxas de parroquias veciñas. Esta mesma informante (B.F., 80 anos), contábanos que antano se dicía que había bruxas no lugar veciño da Bugalla (parroquia de Rebordaos), que dunha vez unha muller mirara -botara mal de ollo- a unha vaca que tiña o ubre moi grande, e que por iso comezara a dar sangue no canto de leite cando a muxían; ou tamén que o seu pai lle contara que tiveran que levarlle a vaca á bruxa para que lle quitara o meigallo (outra vez o mal de ollo). E engadía a muller: "eu neso non creo moito, pero malos ollos pode haber...".

Contábase asemade que naquela parroquia andaban as bruxas pola noite con candeas, polo que se dicía que "había luces na Bugalla". E falando de fachas nocturnas, vén a conto a tradición sobre as Medas de Santa Cruz (lugar veciño da mesma parroquia) tamén relacionada coa previsión contra as meigas.

10 De todos os presentes (entre os 60 e 80 anos), este informante era o máis novo, dunha xeración anterior, o que posiblemente explica ese comentario, máis propio de sobreinterpretacións de orixe culta. 
Antigamente, segundo se conta, a xente poñía lume no cumio dunhas penas redondas que hai antes de chegar ás casas de Santa Cruz, para escorrentar aos "demonios". Poñíanse todo o ano fachas feitas con palla, máis pequenas que as feitas con agucios: “...e aí en Santa Cruz, antes de chegar ó pueblo, hai uns penedos moi feitos, unhas pedras redondas, pois aí tamén había unhas personas que tiñan lume na cima daquelas pedras pa' alumar pa' que non viñeran os demonios de lexos, e entonces vían as fachas de palla e xa non pasaban pa' riba p'a o pueblo, e dicía unha señora: ai, eu na miña casa teño máis velas ca Dios me da, e eran as présas das pallas que alumaban [... ] unha dicíalle ao novio: eiquí somos ricos todos, alumámonos con 100 velas cunha presa de pallas [risas]”

\section{A Cruz das Ánimas}

Chámanlle Cruz das Ánimas e tamén O Cruceiro en Vilelos ao lugar tradicional no que se celebran as verbenas das festas patronais, unha encrucillada de camiños relixiosamente sinalada, como é habitual en Galicia, tanto polo seu topónimo como polo monumento alí afincado. Trátase, neste caso, dun bloque de granito, a modo de estela, gravado coas figuras de tres orantes. Aparece erguido sobre o muro de bloques de cemento que delimita o campo da festa, mirando cara ao camiño que pasa por diante. Na parte inferior da estela, por debaixo do relevo, hai unha inscrición de difícil lectura e outra pedra horizontal provista dunha pía cuadrangular (fig.6) Hai noticias que confirman que no pasado fora un peto de ánimas, pois a xente lembra que se pasaba facendo venias e deixando esmolas nunha caixa pechada con cadeado.

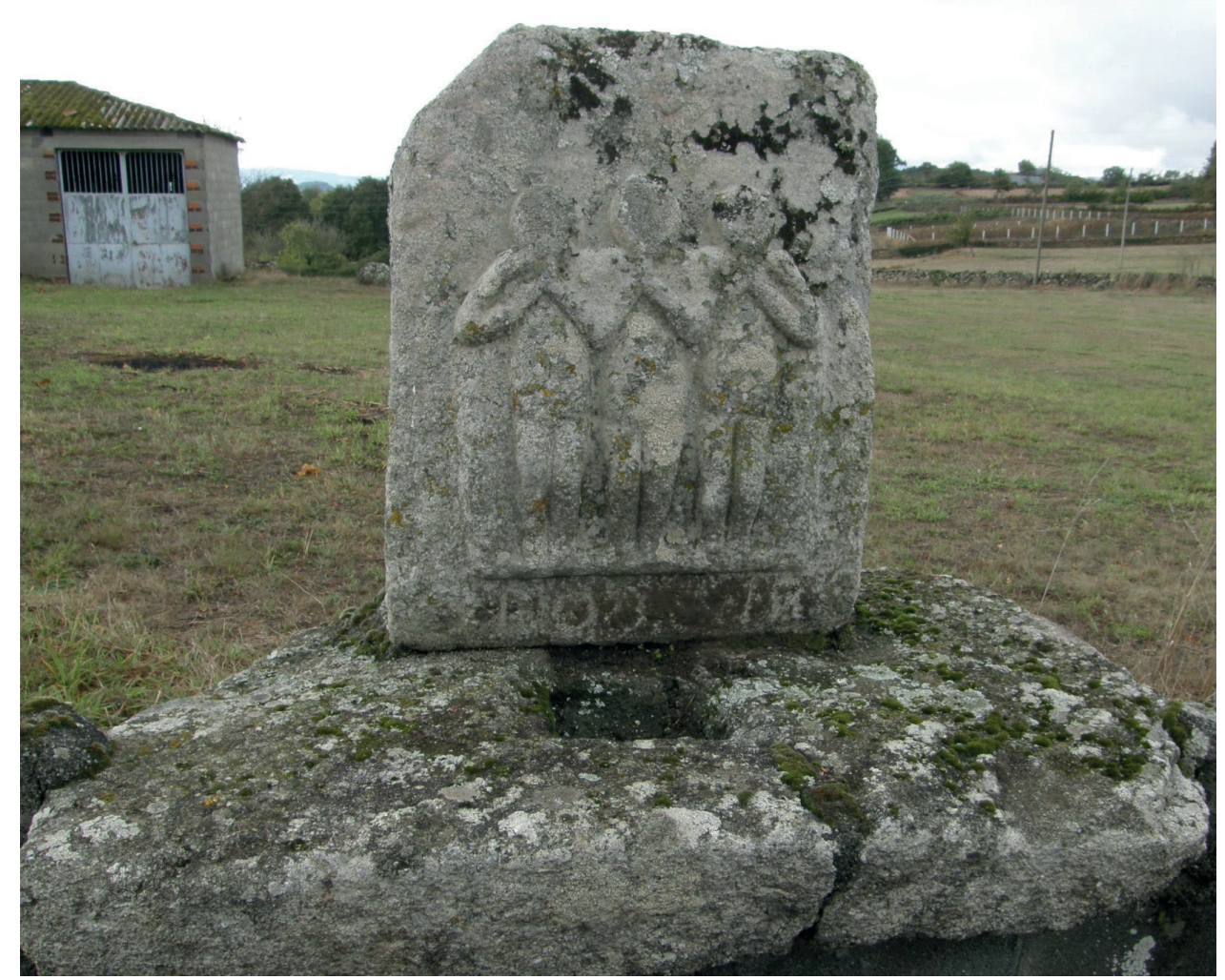

Figura 6 


\title{
Folclore
}

Ao monumento que serviu de peto de ánimas calcúlanselle uns 800 anos de antigüidade, porque disque así consta na inscrición (o que non se puido verificar). Disque tamén procede do castro, dunha capela que había no cumio, aínda que sobre isto tampouco non hai moito acordo. En calquera caso, o certo é que a lenda etiolóxica do peto de ánimas de Vilelos está estreitamente relacionada coa historia imaxinaria do castro, razón pola que se comprende a súa temática caracteristicamente "castrexa".

\begin{abstract}
"Había - contan- un partido de Castro do Rei [de Lemos, Concello de Paradela] e autro de eiquí, que daquelas había entre os pueblos rencores e rencillas. Facían guerras os dous solos, se se daba o caso... E estes luchaban polas ánimas, eiquí nesta parroquia; e os de Castro do Rei..., non sei por que outro partido luchaban. E viñeron -porque citábanse p’o día que tiñan a batalla. Os de eiqui xuntaban xente e os de Castro do Rei traían xente. E os de eiquí matáronlle tres fulanos ós de Castro do Rei. Este luchaba polas ánimas. E foi cando puñeron eso (díceno, que eu non o vin, eh!), foi cando puñeron eso, eses tres fulanos polas ánimas, aí. [...] por eso ten a caixa das ánimas aí. Que había unha caixa. Cada un daba o seu limosna aí, cando quería [...] Eso é certo, eh! [...] A batalla era aí, na Cruz das Ánimas. Non había cruz nin había nada"1.
\end{abstract}

\section{Castro da Besta}

O camiño actual ao castro parte da encrucillada das ánimas. Aínda que non se efectuou ningunha escavación arqueolóxica e a única prospección que coñecemos é a publicada por F. Cuevillas (CUEVILLAS 1953), non parece haber dúbida de que o Castro da Besta é un poboado prehistórico. Coa súa altura relativa respecto ao entorno e a súa característica topografía, coa súa croa ben delimitada e perfectamente visible en fotografía aérea, presenta todos os indicios dun poboado da Idade do Ferro.

\section{Folclore}

O tipo de anécdotas, lendas e contos tradicionais que rodean a este lugar tamén coinciden co coñecido repertorio folclórico dos nosos castros. A realidade e un pouco de tradición mestúranse, por exemplo, na relación dalgúns informantes sobre achados aparentemente antigos alí atopados.

Conta un dos nosos informantes (J.M.C., 59 anos) que, arando no castro, lle apareceu unha pedra labrada cando intentaba achanzar un desmonte como de un metro máis ou menos. Alí apareceu unha pedra de cantería, como de $50 \mathrm{~cm}$ de circunferencia, estrañándolle ver esa pedra no medio do cascallo; e tiña por baixo a forma dun cacharro, da boca

11 F.M. veciño, 79 anos. Non podemos deixar de mencionar a relación que o informante establece entre estas antigas batallas e as típicas liortas que se daban entre veciños de diferentes parroquias durante as festas locais: "en calquera festa había unha batalla de fulanos e tiros e todo. E mortos. Mesmo, eiquí, un do Valentín, matárono [volvendo] de Escairón, aí en Pisqueiras. Pegáronlle un tiro e matárono". 
dunha ola (onde metían o ouro; pero non o había [comenta entre risas]). "E por baixo, no firme, como eso, xustamente o redondel da ola. A ola non estaba, pero xustamente o círculo dela... A pedra está aí xa empleada” [reutilizada no fondo dun pozo].

Tampouco non falta entre as tradicións do castro a influencia da literatura histórica erudita:

F.M.: Non hai castro que non teña un antecastro como ten eiquí. [...] porque eiquí houbo grandes batallas nistes castros, non penses ti que foi...

E.G.: Cando os romanos?

F.M. Estos son celtas! [...] Os antecastros eran cando viñan a... porque aquí había ó millor 1000 ou 2000 homes na cima do castro. Daquelas era todo a pedras. Empezaban no antecastro a tirar pedras. Viña o enemigo... Se o deixaban entrar xa lles ganaban a batalla. Esto non era pa' outra cousa!

[...] Este sitio do Manolo da Besta aí, pode que tuvese vinte tractores de coios, redondiños así, así piquiniños. Todo era das batallas. Daquela non había unha arma nin había nada. Todo era así!"

"Eso todo dos castros era pa'defenderse todo a pedras, ou con ferramentas de pau ou co que podían. Segundo contaban, eh! [...] E os da Casa Grande, por tras do castro pequeno, que lle chamamos o castro pequeno, está tamén de pedra así [acena coa man indicando grande cantidade] O castro, non é decir que o fixeran a cestos de terra; o castro fixérono, como tódolos castros, escavando terra e deixando o corazón do medio á vista. Porque na cima do castro hai canteiras [...]"

Pero o que máis abunda é o folclore castrexo típico: os mouros subterráneos, os tesouros, o pozo, o túnel, a cadea de ouro, as ovellas, etc.

\section{O pozo dos mouros}

"O castro, dicían, dicíano, no sitio que é do José, que alí había un pozo, no sitio do Felipe, que alí que había un pozo, e que había unha entrada ó castro pola parte de arriba, no sitio que é ahora do Valentín, aínda se conoce o canal como está, por alí que había unha entrada, e dicíannos os antepasados que eran os moros os que entraban por alí [...] Polo lado d'alá, no sitio do Valentín, aínda se conoce o muro por donde os antiguos dicían que se entraba pró castro. Que o castro no centro que estaba hueco [...] Eu..., era o que dicían os vellos. E no sitio do José, no sitio do Felipe, índa dende que o colleu Felipe, había un pozo. Habíao.... Dicían! que había un pozo alí” (F.M.)

\section{O Ramiro do Pozo}

"[Ramiro do Pozo] que era un traste do carajo, decía: "Aquí habitou xente, que eu cando era mozo viñen arar, cunhos bois, viñen arar cunhos bois e decíame unha voz de baixo: Ramiro, cerra o arado que nos derramas o tellado! [...] Decía que estaba debaixo habitado polos mouros" (F.M.)

\section{A cadea de ouro}

"Decían os vellos de antes xa, que dende o castro á Laxe de Vilelos que había unha cadena de ouro -e outra de fuego [engade J.M.]- e, co tempo, que a habían de descubrir as ovellas" (F.M.) 
Outros veciños contan o mesmo conto, interpretando a cadea de ouro como un túnel ou mina subterránea que comunicaba o castro coa Laxe, lugar que ten a súa propia historia. Trátase, como o seu propio nome indica, dunha grande laxe ou pena plana, hoxe en boa parte desaparecida e cunha torre eléctrica ao carón.

Interrogados sobre algunha característica especial desa laxe, so sinalan que noutros tempos se utilizaba como eira comunal a onde ían todos os veciños de Vilelos (a aldea, non a parroquia) a airear os chichos -limpar as fabas para quitarlles o lixo- e incluso o pan, cando se facía a malla ao xeito tradicional.

A localización xeográfica da Laxe dentro da parroquia é bastante periférica,

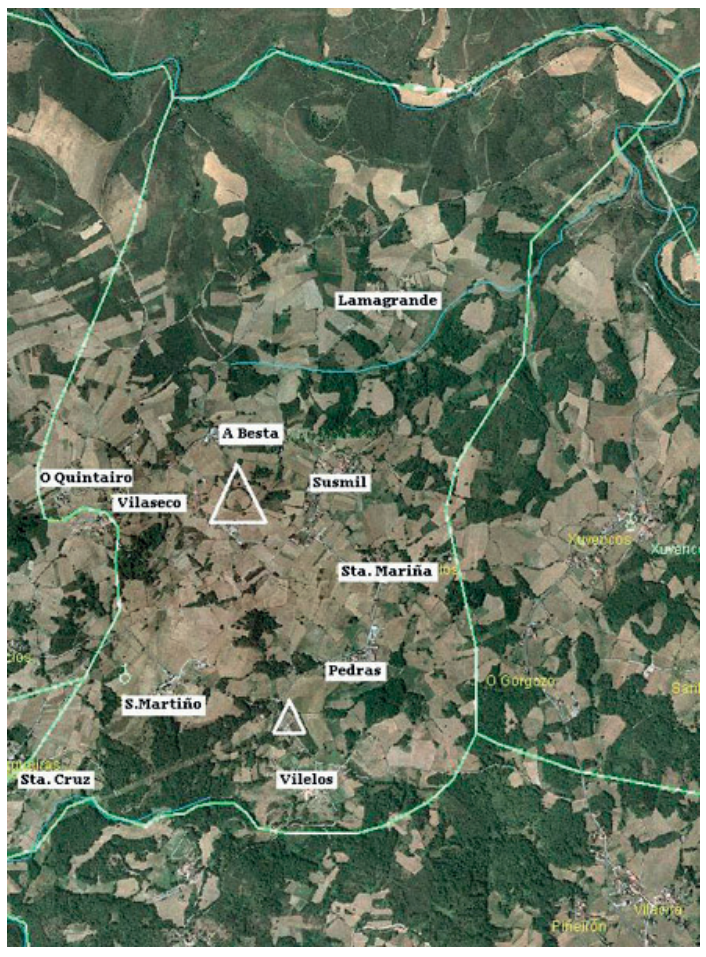

Figura 7. Parroquia de Vitelos. mentres que o castro parece bastante céntrico (sinalados na fig. 7 con triángulos).

A Laxe posuía un claro valor colectivo tanto para actividades agrícolas como para actos festivos, como proba o feito de que era o lugar empregado para celebrar a famosa corrida do galo ao remate da festa das Angustias:

\footnotetext{
"Aí acababan a festa. Facían a festa arriba, non?... e despois a festa que acababan aquí, aquí facían un rito, facían un burato no suelo e metían un capón alí, coa cabeza fóra, e despois poñíanse a unha distancia e tirábanlle pedras e o que mataba o capón levábao (...) Eso era cando se acababa a festa, alí. (...) O do capón a min xa mo contaban os vellos de aquí” (P.M.P, veciño, 51 anos)
}

\section{A SUPOSTA ORIXE PAGÁ dA FESTA}

É moi habitual definir este tipo de festas, nas que interveñen castros e lume, en termos de reminiscencia do antigo paganismo, como en varias ocasións observamos no relato dos nosos informantes, sen dúbida por reproduciren o discurso do Concello, que adoita promocionar o Fulión como "festa castrexa", e reiterando ano tras ano que "Segundo contan os nosos antigos a procesión das fachas facíase, nalgunha época, como ofrenda aos deuses para agradecerlles as boas colleitas".

É certo que o paganismo, entendido como o conxunto de relixións étnicas da Antigüidade anteriores á cristianización, posúe numerosos puntos en común coa relixiosidade popular galega. De entrada, parece evidente que ambas manteñen unhas relacións co medio natural e cos seus elementos (as pedras, a auga, o lume, etc.) alleas á relixión 
oficial católica, que ao longo da súa historia non fixo senón tolerar todas esas crenzas e prácticas, cristianizando moitas delas (poñéndoas baixo a advocación de diferentes santos e a dirección dos sacerdotes católicos, por exemplo).

Boa proba de que moitas daquelas prácticas foron en primeiras obxecto de crítica e desaprobación por parte dos xerarcas da Igrexa, ofrécenola aquel famoso sermón de San Martiño de Dumio, bispo de Braga, dirixido aos "rústicos" ou campesiños galaicos do s. VI d.C, para corrixir a súa actitude ante a relixión e as súas, consideradas polo santo, perversas supersticións. Entre as súas recriminacións, incluíanse os costumes de prender cirios a carón das pedras, árbores, fontes e encrucilladas, practicar a adiviñación e os agoiros, poñer loureiros, botar pan ás fontes, etc. Existen poucas dúbidas de que San Martiño censuraba aquí hábitos e ritos propiamente pagáns, nos que se recoñecen numerosas prácticas da relixiosidade popular galega (LÓPEZ PEREIRA 1996; BANDE RODRÍGUEZ, E. 1997)

Pero non é a nosa intención aquí afondar no tema das chamadas "supervivencias" pagás, tema intensamente discutido tanto no terreo da Antropoloxía como da Arqueoloxía ou a Historia (v.g. APARICIO 1999: 322 ou QUINTÍA 2012: 13), senón simplemente aclarar por que non se pode falar do noso Fulión como dunha festa "castrexa", arqueoloxicamente falando (é dicir, dunha festa "prehistórica”).

\section{"SER CASTREXo" OU "SER No CASTRo"}

Nas parroquias nas que se celebran este tipo de festas sobre castros prehistóricos é habitual escoitarlles aos veciños interpretacións sobre unha orixe prerromana, celta ou precristiá da mesma. Pero é moi difícil poder aceptar esta suposta orixe, pois é moita a distancia que separa a concepción do espazo que imperaría naqueles poboados nos remotos tempos da súa ocupación, da máis recente visión espacial do castro nas parroquias actuais.

De partida, o castro prehistórico era o lugar de habitación dos seus construtores, mentres que, tras ter sido abandonado, cambiaría radicalmente de carácter para se converter nun territorio entre "imaxinado" (lembremos o folclore do castro da Besta) e economicamente explotado.

Aínda que non sabemos dende cando o castro foi obxecto de explotación agrícola ${ }^{12}$, hai que ter en conta que en ningún caso estas zonas elevadas responden á pauta “ideal” de uso tradicional das terras de cultivo na parroquia galega. Dende época galaico-romana, o poboamento antigamente castrexo desprazouse cara ao val (concentrándose en torno ás villae ou facendas rústicas romanas), posto que se buscaba precisamente a proximidade ás terras más fértiles. Dende aquela, o hábitat rural ocupou xeralmente as zonas de media ladeira, para non invadir as terras de cultivo, que seguían manténdose nas terras

12 Se ben anteriormente recollemos a noticia de que o castro sempre fora labrado, un veciño de 78 anos dicíanos: "O castro antes non se traballaba. Bueno, o único que o traballaba era o Xusto de Vilelos, que o demais estaba todo a monte. Nin pasto nin nada [...] O castro empezouno a traballar dende que partiron os de Rei de Pedras [...] sólo traballaban unha parcela". 
baixas, máis profundas e produtivas. Neste sentido, o castro adoitaba ser un espazo de aproveitamento colectivo de recursos de monte e canteira, para a construción da casa campesiña, do pazo ou da igrexa.

Por outra parte, non debemos esquecer que, segundo o folclore da parroquia, o castro estaba ocupado polos mouros, os habitantes doutra raza, pagáns e costumes xeralmente noctámbulas que se aparecen en todos os espazos fisicamente marxinais da xeografía rural galega (é dicir, non transitados a diario polo campesiñado) ${ }^{13}$. Aos mouros hai que engadir as bruxas que, como vimos, son o obxecto específico de persecución na noite de vésperas.

O sentido ritual da Festa das Fachas, por conseguinte, debe interpretarse coas connotacións propias deste tipo de lugares dentro da cosmoloxía campesiña; ha de implicar, dito noutros termos, a consideración do castro como un espazo pouco ou nada humano, ocupado por seres externos á sociedade "normal”, que son considerados alleos á moral cristiá e, por tanto, incontrolables e perigosos. Por tanto, a pesar da súa localización céntrica respecto á xeografía actual da parroquia, o castro ocupa conceptualmente un espazo, pode dicirse, periférico.

Pero a festa de Vilelos implica outros diferentes elementos míticos ademais do castro, que é necesario considerar, tanto independentemente como nas súas mutuas relacións.

\section{O universo Mítico do Fulión de Vilelos}

A etnografía de Vilelos mostra un rico imaxinario sobre o espazo circundante, un espazo cargado de valores sociais e simbólicos representados por moitas das formas comúns a través das cales a vella cosmoloxía galega representaba "o sagrado", razón pola que tamén son espazos con valor fundamentalmente ritual: o castro, a laxe e a encrucillada. Eses elementos espaciais característicos conflúen ademais cos personaxes imaxinarios que tipicamente se lles asocian, como son os mouros, as ánimas e as bruxas. Analicemos máis polo miúdo cada un destes compoñentes.

Como dixemos anteriormente, o castro é a casa dos mouros, pero unha casa subterránea; por iso se considera que está oco por dentro, que se aras a terra lles estrapallas os tellados das casas e que hai un pozo de entrada ao seu interior (cf. conto do Ramiro do Pozo).

Moitos dos lugares habitados e transitados habitualmente polos mouros posúen algúns trazos comúns: ou se trata de lugares de paso (como pontes, camiños e encrucilladas), ou de lugares acuáticos (ríos e fontes), ou ben sitios destacados na paisaxe, que foron tradicionalmente empregados para trazar os límites entre aldeas, parroquias, dioceses ou calquera outra liña fronteiriza de tipo político-administrativo. Neste apartado inclúense os montes, os outeiros e a maioría dos xacementos arqueolóxicos prehistóricos (castros, mámoas, dólmenes, gravados rupestres...,), así como outros elementos naturais

13 Para unha completa caracterización dos mouros ver LLINARES 1990, 1990a. Sobre as conexións entre arqueoloxía e folclore castrexo: ARIZAGA e AYÁN 2007; FREÁN CAMPO 2015. 
de semellantes características (grandes penedos, covas, penas furadas ou con formas curiosas que parecen ser produto da intervención humana, etc.; FERRO COUSELO 1952; APARICIO CASADO 2002).

A tipoloxía formal de todos estes sitios é moi variada, pero algo común a todos eles é que se consideran lugares sagrados, precisamente polo seu carácter simbolicamente fronteirizo. Por esta calidade de lugar de encontro entre espazos diferentes, neles ten preferentemente o contacto co Outro Mundo, polo que alí se celebran moi diferentes clases de rituais, dependendo das forzas sobrenaturais que se invoquen en cada caso: bautismos, ritos curandeiros, funerarios, exorcistas, etc.

Tanto o folclore de Vilelos como a súa festa establecen unha liña de conexión directa entre o Castro da Besta e un típico gran penedo raso, de nome xa suficientemente significativo: o lugar da Laxe. No folclore do Castro, a Laxe sinala o extremo da cadea de ouro que une ambos os lugares. Durante a festa, outra cadea volve xuntalos, aínda que esta vez nunha dimensión temporal: o castro abre o inicio das celebracións durante as vésperas (o fulión), mentres que a Laxe as cerra coa corrida do galo celebrada o último día.

Noutros lugares do rural galego, trabes, minas subterráneas e cadeas de ouro adoitan unir espazos xeográficos das características sinaladas anteriormente para os "lugares sagrados", como podemos observar neste esquema elaborado a partir dos datos subministrados por LLINARES (1990a: 123):

- o castro adoita estar unido a: outro castro, fonte, lugar concreto do monte, río, mar, penedo, ponte, igrexa, convento

- a mina ou pozo: a un múño

- o penedo: a un lugar concreto do monte

- o río: a pozos, covas e capelas

- a fonte: á igrexa

Evidentemente, o carácter sagrado de capelas, igrexas e conventos provén directamente do seu carácter relixioso; o mar, porque é un dominio do que se exclúe todo o maligno (ningún demo pode meterse nel) e outros lugares, como ríos, fontes, pozos, penedos, covas e lugares concretos do monte son, como dixemos, lugares habituais das mouras e onde adoitan localizarse os "tesouros dos mouros", que o campesiño sabe como conseguir mediante rituais específicos de "desencantamento" (VVAA 2012)

O único elemento aparentemente distorsionante neste esquema é o muíño. É certo que a súa posición dentro da aldea é bastante arrecantada (ao carón do río) e, quizás por iso, ás veces se pode escoitar aos mouros moer nel pola noite. Pero tamén se trata dunha construción enteiramente humana, un lugar de traballo perfectamente integrado nos labores cotiás da vida campesiña e ata lugar de encontro entre moitos veciños, incluso pola noite (durante "as muiñadas"). Xustamente ao igual que as igrexas. Pensamos se este tipo de lugares en concreto non estarán reflectindo, na mentalidade campesiña, a mesma posición que un desencantamento exitoso. Os lugares do Fulión, pola contra, parecen os típicos espazos nos que ese desencantamento sería potencialmente posible. Vexamos. 
A relación ideal que pensamos que une a todos os lugares mencionados (incluídos igrexas e muíños) é a súa conexión coa idea de tesouro, é dicir, de riqueza. No caso que nos ocupa, o castro da Besta e a Laxe aparecen unidos por unha "cadea de ouro", que é unha conexión típica de espazos mouros (castro-penedo singular), traducíndose esta conexión simbólica nunha relación real na cadea produtiva da aldea: se no Castro se apaña materia prima (madeira ou pedra) xurdida de maneira case espontánea, ou incluso se sementa e colleita, na Laxe ten lugar unha actividade agrícola posterior, o aireado dos chichos e do pan, o que se fai aínda despois da sega e da malla. Compréndese, logo, que estes dous cabos da liña produtiva agrícola se convertan no imaxinario nunha cadea de ouro capaz de conectar dous espazos produtivos, provedores de riqueza.

Por conseguinte, podemos soster que Laxe e Castro son depositarios privilexiados de tesouros en canto lugares onde a riqueza se manifesta material e realmente, co produto ben logrado das colleitas ${ }^{14}$. Entre os desexados tesouros dos mouros e a transferencia desa riqueza cara á sociedade campesiña media xeralmente, nos contos populares, o "desencantamento", que é o procedemento por medio do cal o paisano, mediante unha proba de valor, é quen de apropiarse dese tesouro agachado nos espazos mouros.

O "encanto" é a maxia empregada polos mouros para manifestarlles aos humanos migallas das súas grandes riquezas subterráneas e subacuáticas, a pequena parte que están dispostos a compartir con humanos merecedores dunha pequena recompensa. $\mathrm{O}$ xeito de compartírena é mostrar en superficie parte dese tesouro baixo distintas aparencias: a galiña coa rolada dos pitos de ouro, a moura tendeira aparecida no castro coas súas tesoiras de ouro ou na fonte peiteando os rubios cabelos co peite tamén dourado, etc. En todos estes casos aparécense os mouros probando mediante un desafío a madurez do campesiño ou campesiña que se cruza no seu camiño, para en consecuencia castigalo ou recompensalo. Pero a máis grande promesa é sen dúbida a princesa moura encantada polo rei mouro con todos os seus abundantes tesouros, que se presenta en forma de serpe á que hai que bicar ou arrincarlle o caravel da boca ${ }^{15}$.

O mito da moura-serpe, a que máis tesouros dispensa no imaxinario colectivo, é simple alegoría das capacidades que necesita o home campesiño para lograr unha vida próspera e plena: arrincarlle o caravel á serpe, entendido como desfloramento dunha virxe, demostra madurez sexual, e por tanto a capacidade para casar e formar familia propia. A virilidade convértese, por tanto, en fonte ou posibilidade de toda riqueza, e sobre ese "valor superior" diríamos que gravita toda a sociedade tradicional galega, da que non se exclúe o noso Fulión, como veremos.

A cadea de ouro que une o Castro da Besta coa Laxe sinala, como dixemos, a conexión entre dous dos lugares de acción colectiva e ritual máis salientables dentro da xeografía

14 Non é estraña a idea de que o mallo (instrumento da malla) pode "contaxiarse", por contacto, das virtudes da terra que gardan os tesouros. No lugar de Laxos (Sta. María de Cuntis), fálase dunha eira na que había un pote de ouro e que "cando mallaban o trigo, cos manles", para que "tocaran ben" (ou fosen eficaces), os enterraban nesa eira (AYÁN VILA 2002: 161).

15 A posibilidade de desencantar a unha moura-serpe e conseguir as súas riquezas está limitada ao home, que ha ser valente e non estar casado, pois a súa finalidade é desposar á muller encantada. Pero dos tesouros mouros pode beneficiarse calquera, sempre e cando dispoña de boas aptitudes: honradez, discreción e, sobre todo, falta de cobiza. Calquera defecto nalgunha destas virtudes supón automaticamente o fracaso no desencantamento; ver LLINARES 1990. 
da comunidade. Sen embargo, a etnografía coñecida non revela que a Laxe represente no imaxinario local ningunha conexión co castro durante a corrida do galo que alí se celebra. Esta cerimonia é a típica actividade masculina, na que os homes compiten en destrezas, neste caso en puntería. O gañador leva o galo en recompensa, ademais do recoñecemento público do dominio dunha competencia tan propia de homes.

Lembremos que os mesmos valores competitivos que vemos na corrida do galo, que remata a festa das Angustias en Vilelos, estaban tamén presente no concurso das fachas do día de vésperas, estando en ambos os casos as dúas actividades limitadas á participación dos homes da parroquia. Estes feitos van ter especial significación cando consigamos desensarillar este complexo universo folclórico.

Entre os espazos míticos que mencionamos no apartado etnográfico, fáltanos por tratar a Cruz das Ánimas, o cruce de camiños que comunica o castro co campo da festa e o resto dos lugares da parroquia ${ }^{16}$.

O folclore galego das encrucilladas foi obxecto de estudo por parte de J. TABOADA CHIVITE (1975), despois do cal coñecemos mellor os elementos que conflúen na caracterización deste espazo singular. O cruce de camiños, sabemos que dende Antigüidade, é un dos lugares predilectos de encontro co Outro Mundo, entendido este en todas as súas dimensións: como o outro mundo dos mortos; como o outro mundo do demo e dos seus secuaces (as bruxas); como o outro mundo de calquera manifestación sobrenatural que poida imaxinarse (como a cura milagreira ou máxica de moitas doenzas).

Na encrucillada aparécese pola noite a Compaña de mortos, que introduce aos vivos que se encontra polo camiño na súa comitiva fantasma, a non ser que coñezan os diferentes remedios para evitalo. Tamén se presentan as ánimas condenadas para que lles "rompan o hábito", a mortalla bendita que lles impide entrar no Inferno, e as ánimas en pena do Purgatorio para facer pedidos e solicitar que se rece pola súa salvación. Polas mesmas razóns, teñen lugar nos cruces diferentes rituais relixiosos, como o bautismo prenatal e outros de carácter funerario, xeralmente asociados ao monumento cristián que tantas veces sinala este espazo sagrado: o cruceiro. Aos seus pés entérranse os nenos sen bautizar e no seu pousadoiro póusase o féretro de camiño ao cemiterio para rezar os responsos polo defunto.

Na encrucillada, en fin, invócase ao Demo para conseguir os poderes da bruxería (o "pauto co demo"), reúnense as bruxas e extráese a terra que se emprega nos feitizos, aínda que, ou polo mesmo, tamén se montan as fogueiras para escorrentar ás meigas e se curan diferentes aires, ademais do meigallo (CUBA et al. 1999: 110-1).

En definitiva, caben poucas dúbidas do carácter máxico e eminentemente sagrado que o imaxinario popular galego atribúe a estes lugares de tránsito cara a direccións diverxentes. Polo mesmo, non sorprende que o noso Cruceiro de Vilelos estea dedicado ás Ánimas.

16 Un parágrafo do documento emitido pola Comisión de Festas (2003) antes mencionado, deixa constancia de que se trataba dun lugar de tránsito importante: "Niste pobo e nun cruce de camiños era e é, donde se fai a verbena. Había e hai un peto de ánimas, unha pousada chamada Carrancova e unha casa que tiña unha luz de candil sempre encesa para guiar peregrinos que iban camiño de Santiago que lle chamaban e chaman a Candelexa no Quintairo. Sigue o camiño ata Pincelo en donde para atravesar o río Miño había que facelo en barca". 
As relacións entre os vivos e as almas dos defuntos establécense na forma de intercambios recíprocos. Os vivos rezan polas ánimas, ofrécenlles misas e procesións polo seu descanso eterno. En troques, as ánimas, "los del otro mundo alejan las pestes que diezman los animais domésticos, dominan las tormentas que amenazan las cosechas, atraen la lluvia necesaria cuando la sequía asola la comarca y hacen aparecer los animais y objetos perdidos" (MANDIANES 1996: 205).

Dentro desta reciprocidade debe comprenderse aquela noticia dun dos nosos informantes segundo a cal "o dos lacós era aparte. Xa non iban pa' beneficio da festa, iba pa' beneficio do cura". En realidade, o máis probable é que, dentro dos escotes para a festa, a parte do porco que cedían os veciños fose destinado ás ánimas, como é habitual noutras partes do país, onde tamén se poxaba polas súas pezas (MANDIANES 1996: 209; CASTRO PÉREZ 1991: 252).

O produto campesiño máis prezado destínase ás ánimas, porque é moita a contrapartida que se espera delas: que eviten as pestes dos animais e a súa perda, que afasten as treboadas que prexudican as colleitas, que atraian a choiva cando fai falta. Diríase que o benestar da comunidade depende en boa medida dos favores dos defuntos.

Outros aspectos máis propiamente simbólicos das ánimas cobran sentido á luz dos datos sinalados. A iconografía común das ánimas como personaxes descalzos ("ninguén veu xamais unha ánima calzada", Cf. MANDIANES: 1996: 208) ten moito que ver con estes poderes que se lles atribúen. A mitoloxía clásica coñece varios exemplos que relacionan o pé descalzo coa potencia sexual viril (que para eses momentos vale dicir "reprodutiva"), e a paremioloxía galega pon en xogo este tema comparando o "calzar" cun coito exitoso (LLINARES 1990a: 162): "De riba de ti estou, debaixo de min te teño, ben pouca sorte é a miña, se non che meto o que teño" (a zoca); "Enriba de ti me poño, debaixo de min te pos, se non che meto o que teño, pouca forza me deu Dios" (meter o pé na zoca)

Que a esperanza reprodutiva do mundo campesiño descanse na imaxe dun pé descalzo (pero que quere calzar), permite comprender mellor por que para favorecer a fecundidade as mulleres lavan os seus zapatos (metáfora dos seus xenitais) en augas milagreiras, ou que para escorrentar ás bruxas (as grandes causantes de pragas en todos os ámbitos, humano, animal, vexetal), sexa preciso facer unha fogueira nunha encrucillada cun pouco de loureiro (herba sagrada) e unha sola de zapato (CUBA et al. 1999:111), metonimia da meiga causante da infertilidade.

A partir desta confrontación dos valores simbólicos respectivos de ánimas e bruxas podemos concluír que as ánimas son depositarias da esperanza campesiña nunha vida máis segura, próspera e saudable. Sen embargo, cando na lenda etiolóxica do peto de ánimas do Cruceiro se dicía que "estes luchaban polas ánimas, eiquí nesta parroquia; e os de Castro do Rei..., non sei por que outro partido luchaban," parece darse a entender que as Ánimas teñen capacidade de protexer aos seus non so contra os inimigos sobrenaturais, senón tamén contra os seus iguais, eses veciños eternamente rivais contra os que intenta afirmarse a comunidade parroquial, posto que "en calquera festa había unha batalla de fulanos e tiros e todo", fenómeno habitual nas festas parroquiais galegas.

En calquera caso, sabemos que as Ánimas tampouco non son a única esperanza contra as ameazas sobrenaturais, pois se figuran moitos máis procedementos para previrse 
contra elas. Unha desas ameazas, posiblemente a máis perigosa, son as meigas ou bruxas. Podería dicirse que son o reverso das ánimas, posto que atentan xustamente contra todo o que aquelas protexen. O folclore sobre as bruxas en Galicia conta cunha vasta etnografía, da que aquí só interesa subliñar as liñas fundamentais ${ }^{17}$.

A meiga ou bruxa é un personaxe que se move no imaxinario galego entre o real e o ficticio, posto que ao mesmo tempo que refire a veciña máis ou menos corrente, experta en adiviñación e curas máxicas (podendo ser profundamente relixiosa ou católica), tamén pode designar á bruxa malvada que, tendo realizado un "pauto co demo", posúe poderes malignos e bota man deles (mal de ollo, meigallo) para prexudicar aos veciños, enmeigando aos seus fillos e a súa facenda (gando e colleita) ${ }^{18}$. No caso de Vilelos, podemos observar a dicotomía entre esas dúas formas de bruxería no mesmo informe, precisamente no contexto da Festa das Fachas:

"O das bruxas si, tiña moito auge. Deso acórdome, acórdome, das fachas e de que decía a abuela, a miña abuela, que en paz descanse, a Cabaza, que era... meiga, mui... mui santona, rezaba moito, tiña o rosario... Decía: Ide cidillo ide, ide cidillo ide, a ver se non veñen as bruxas".

Esta distinción entre meiga (muller relixiosa) e bruxa (perigosa), que non é en absoluto estándar na etnografía galega, informa en todo caso sobre esa diferenza fundamental entre a meiga que presta un servizo social e a que é sospeitosa de perpetrar maldades. No caso que nos ocupa, interésanos máis as bruxas malignas, posto que son elas as que se pretende espantar co fulión e as fachas.

Fulión e fachas son facilmente convertibles en ruído e lume, dous dos elementos empregados tradicionalmente para protexerse contra o mal, contra o demo e as bruxas. É ben sabido que as campás se fan repenicar para espantar as treboadas e os personaxes imaxinarios que as provocan, tronantes e nubeiros (CUBA et al. 1999: 68). Igual estrondo producen as "tamborradas" do primeiro de ano ou do carnaval, cando acompañan á queima e expulsión da aldea do Meco, que representa ao Demo ou Inimigo (TABOADA CHIVITE 1969: 213). Que o fulión traduza precisamente esa idea de "follón", dun balbordo producido polos cuartetos ou bandas de música e por grande cantidade de pólvora, poderá relacionarse cos procedementos anteriormente citados e con esa mesma finalidade.

Como tamén é ben sabido, o lume funciona en todas as sociedades antigas e tradicionais como un instrumento de purificación, como un dos principais medios profilácticos fronte a posibles ameazas sobrenaturais contra a saúde e o benestar das persoas, dos animais, das colleitas... As festas de San Xoán, co seu riquísimo folclore e rituais, son posiblemente as que mellor documentan os feitos mencionados (GONZÁLEZ REBOREDO 1989). Con todo, tamén sabemos que outras moitas festas ao longo do ano empregan o

17 Ben sintetizadas en CUBA et al. 1999: 57-9. Estudo máis pormenorizado en LISÓN 2004.

18 A caracterización social das bruxas/meigas que a veciñanza personifica en determinadas mulleres da aldea, é a da muller que vive soa, xeralmente solteira ou viúva e tirando a vella, que provoca receos por esa situación anómala que a converte nunha "muller libre", sen o control de calquera home da súa familia ou marido. As bruxas forman parte dese paradiogma cultural mellor definido pola moura, cuxo principal destino como figura mítica é ser desencantada, é dicir, sometida ou domesticada por un home. 
lume, posiblemente con fins semellantes: coñecen o seu uso o "tizón de Nadal”, a noite de San Silvestre (fin de ano), o Carnaval, os Maios, San Xoán, San Pedro, San Roque, etc. A súa presenza é tan habitual, que resulta difícil sistematizala (GONZÁLEZ e BUXÓ 1997). Con todo, parece haber acordo en que este lume ritual aparece en escena en momentos especialmente críticos dentro da concepción do tempo campesiño, é dicir, nos momentos transitorios entre diferentes tempos (diríamos "encrucilladas temporais"): entre as estacións do ciclo agrícola, que moitas veces reflicte o propio calendario relixioso, pero tamén en momentos nos que o anormal ou extraordinario se introduce de súpeto na vida cotiá da xente, que pode ser calquera festividade local. Neste momento tamén se suspende o tempo regulado da vida cotiá, déixase de traballar nos labores diarios e o tempo "se abre" ao diferente ou excepcional, que tanto pode ser o lecer, a esmorga, o ritual colectivo, como o sobrenatural, que aproveita esa fenda para introducirse e trastornar un pouco máis a vida deses días anómalos.

Aínda que o tempo preferido polas meigas ou bruxas sexan os solsticios de verán e inverno (San Xoán e San Silvestre, MARIÑO FERRO 1984), non cabe dúbida de que tamén se deixan sentir no tempo da festa parroquial de Vilelos.

Ao lume purificador que escorrenta ás meigas e o meigallo, máis ao balbordo do fulión, engádese outro factor que aínda non comentamos e que reforza en boa medida a acción protectora destes dous mecanismos apotropaicos, de protección máxica: o propio home e os seus atributos virís. Ademais dos xestos e rituais mencionados, existen instrumentos de protección cuxo poder místico deriva dun atributo físico común: o seren aguzados. En efecto, de todos os amuletos galegos previstos contra o meigallo, a nota común á maioría radica nesa calidade, compartida por coitelos (que "protexen, cortan e atacan a envidia"), cornos, dentes (como os do allo) e, tamén dentro desta categoría, o pene. $\mathrm{O}$ máis famoso dos nosos talismáns contra o meigallo, a figa, con presenza xa coñecida na Antigüidade, suponse que representa un pene en pleno acto sexual (ou máis propiamente un coito) e aínda que non coñecemos amuletos no noso país consistentes en simples figuras de bronce con forma de pene, como os usados polos romanos (BRAÑAS 2005), existen formas e xestos recollidos na etnografía do meigallo que reproducen sen lugar a dúbidas o mesmo instrumento e intencionalidade. Así, entre os procedementos empregados para evitar a mala influencia da bruxa, LISÓN (2004: 179-95) menciona, ademais de facer o xesto da figa coa man ou botar unha punta da camisa por fóra dos pantalóns (forma apuntada), tamén mexar cara a muller da que se sospeita que é meiga.

LISÓN (2004:191) chega a propoñer que o conxunto dos diferentes instrumentos de protección contra as meigas serían máis ben formas metafóricas ou substitutivas do pene, onde radicaría ao cabo a "manifestación e compendio" de todo o poder. Esta proposta ten todo o sentido, posto que o poder destrutor da meiguería só pode ser contrarrestado, loxicamente, por unha forza máis poderosa de sentido contrario. E que pode ser máis contrario á destrución nunha comunidade patriarcal que o poder de xeración/ creación do órgano xenital masculino?

Nas vésperas de Vilelos, de feito, só os homes interveñen activamente na ronda de fachas. Por que nin os curas (cuxa presenza no fulión é indiferente, posto que non interveñen nas vésperas) nin as mulleres participan nela?. Podemos dar resposta a es- 
tas preguntas aplicando as deducións de LISÓN: o cura, pola súa obediencia á norma do celibato, representa a negación da sexualidade, estando por conseguinte desprovisto (simbolicamente) do atributo que realmente é eficaz contra as bruxas. As mulleres, pola súa vez, "por su constitución biológica, por su misma naturaleza, es agente del desorden comunitario, causa el mal, y concluyendo: el hombre es su complemento polar opuesto; a través de su masculinidad, de su propio miembro viril, se enfrenta a la feminidad, la domina literalmente -la "gobierna"- destruye la agresividad, la maldad, cura" (LISÓN 2004: 195)

Durante os rituais que abren e pechan a festa parroquial, o fulión das fachas e a corrida do galo, a metade dos membros da comunidade teñen só unha presencia pasiva pola súa ineficacia á hora de garantir o equilibrio, a harmonía e a prosperidade comunitaria que se pretende asegurar mediante estas dúas celebracións. Só despois de que as bruxas se exorcizan, ten lugar o encontro coas mulleres durante o baile, que non por casualidade se celebra na zona e o tempo intermedio entre ambos os rituais: na Cruz das Ánimas, e xa non só durante o fulión, senón durante todas as festas parroquiais ${ }^{19}$. Deste encontro debe esperarse, e non só simbolicamente, que xurdan as condicións necesarias para que a comunidade se reproduza fisicamente, para o cal agora si é imprescindible a participación das mulleres. Logo do tempo de festa, propicio ao contacto entre os sexos, os encontros han de moderarse para impedir os excesos, e é aí onde, finalmente, entra en escena a corrida do galo, como veremos máis adiante.

Pero preguntarémonos por que compiten os homes. Parécenos unha boa resposta supoñer que a competición, o acto de medir forzas, é o mellor xeito de manter vivo o afán por superarse e desenvolver as calidades virís. Entre os grupos de mozos e rapaces, que son os destinados a levar as fachas ${ }^{20}$, é consecuente pensar que necesiten afirmarse na mellor posición ou consideración social posible, porque neles deposita a familia o orgullo da súa casa e a comunidade enteira a esperanza de prosperidade e futuro. A saúde e o vigor dos mozos da parroquia exprésase na habilidade que demostran na elaboración das fachas, como tamén a súa pericia e destreza na corrida do galo. A simboloxía desta competición, sen embargo, sitúase no punto oposto debido ao significado peculiar que o galo adquire no imaxinario popular (non só en Galicia).

A corrida do galo, como é ben sabido, estaba moi estendida por toda Europa e especialmente, aínda que non só, durante o Carnaval, contexto no que COCHO (1990: 193) sintetiza o seu significado con estas palabras: "O galo é un símbolo da luxuria exacerbada, do exceso carnal e do insaciable apetito sexual. O sacrificio do galo nas distintas modalidades [...] reais ou simbólicas, pon fin a un tempo de tolerancia e incluso de desenfreo". O tempo de tolerancia e desenfreo ao que se refire aquí non ten paralelo exacto na festa parroquial, pero non por iso deixa de ter sentido que se queira controlar a desorde moral dentro da parroquia e que isto se execute durante a festa do santo patrón, cando todos os

19 A saída dende as Ánimas cara ao castro e a conseguinte circunvalación da croa e retorno ao punto de partida, sinala o típico "rito circular" parroquial (independente da procesión relixiosa, que tamén se celebra, e é completamente laico) destinado a reivindicar a importancia dos lugares circunvalados, que dese xeito se reclaman da parroquia e marcan o lugar de partida como o auténtico centro, neste caso a Cruz das Ánimas. Sobre estes rituais e o seu sentido, FDEZ. DE ROTA 1984: 142-143

20 Lembremos que mozos solteiros son tamén os únicos que teñen capacidade para desencantar ás mouras e os seus tesouros. 
signos sinalan cara ao propósito de manter e reproducir a orde social establecida durante un tempo de "certo" relaxo.

Desta maneira, pechamos o círculo: os homes coas súas fachas combaten o "defecto sexual" representado polo meigallo ou influencia das bruxas, o que produce a infecundidade humana e agro-gandeira; o home contra o galo combate o "exceso sexual" ao que pode conducir un contacto íntimo excesivo coa muller propiciado polas festas. O exceso sexual provoca a desorde social dentro da comunidade porque é socialmente estéril (é dicir, non se enfoca cara á procreación de fillos lexítimos). Trátase esta dunha ameaza tan perigosa como a que se exerce en sentido contrario, posto que ambas provocan a inseguridade, a perda de control e o caos.

\section{Conclusión}

Encontrámonos aquí, en definitiva, coa mesma ensinanza moral que se extrae dos contos populares sobre os fracasos nos desencantamentos do tesouro mouro: o fallo resulta sempre dunha falta que, ben por defecto (inmaturidade), ben por exceso (ambición), conduce irremediablemente á perda do tesouro.

Todos os compoñentes desta festa, en definitiva, redundan nunha finalidade exorcizante, para o cal a comunidade mobiliza todos os seus poderes e aliados imaxinarios: as ánimas, o fulión, o lume e a forza viril dos seus membros. O inimigo son as bruxas e todo o que representan, os valores negativos da feminidade, a doenza, a esterilidade e a desorde social e moral que impide o feliz desenvolvemento dun grupo local profundamente patriarcal na súa ideoloxía e funcionamento.

A "cadea de ouro" que une o Castro da Besta coa Laxe é como unha cadea simbólica estruturada en torno a acontecementos, espazos, tempos e metáforas opostas, que se moven entre o real e o imaxinario, o centro e a periferia, o principio e o final, o defecto e o exceso, simbolizando o modo no que a parroquia enfronta ideoloxicamente e executa ritualmente a súa protección contra a ameaza do caos.

O cadro estrutural que mostra a orde e participación dos múltiples elementos e factores que interveñen na consecución dese obxectivo último, podemos ilustralo como segue:

\begin{tabular}{|c|c|c|c|}
\hline \multirow{2}{*}{ TEMPO } & COMEZO & INTERMEDIO & FINAL \\
\cline { 2 - 4 } & $\begin{array}{c}\text { Vésperas } \\
\text { Fulión, Fachas }\end{array}$ & Baile nocturno & $\begin{array}{c}\text { Festa parroquial } \\
\text { Corrida do galo }\end{array}$ \\
\hline \multirow{2}{*}{ ESPAZO } & PERIFERIA & CENTRO & PERIFERIA \\
\cline { 2 - 4 } & Castro da Besta & $\begin{array}{c}\text { Cruz das Ánimas } \\
\text { (encrucillada) }\end{array}$ & A Laxe \\
\hline FREGUESES & Homes & Homes e mulleres & Homes \\
\hline $\begin{array}{c}\text { PERSONAXES } \\
\text { IMAXINARIOS }\end{array}$ & Bruxas (exorcizadas) & Ánimas & Mouros (desencantados) \\
\hline RIQUEZA & Tesouro mouro (prosperidade potencial) & Tesouro das ánimas (peto) & $\begin{array}{c}\text { Tesouro campesiño } \\
\text { (prosperidade actual: colleitas) }\end{array}$ \\
\hline SEXUALIDADE & Defecto & Encontro fecundo & Exceso \\
\hline VALOR MORAL & Desorde & Harmonía & Desorde \\
\hline
\end{tabular}


Este esquema estrutural non oculta que tras a orde dos acontecementos se impón unha lóxica causal. Logo de que se neutraliza o poder das bruxas mediante o rito do fulión, danse as condicións para o bo logro das colleitas e o encontro sexual normal entre homes e mulleres, cuxo produto se manifesta na Laxe, mesmo lugar no que se cerra o ciclo produtivo das colleitas (co aireado das fabas e o cereal) e tamén o das mulleres (coa corrida do galo). O que subxace no fondo de todo este complexo mundo, segundo pensamos, non é máis que unha grande lección moral acerca do único medio de conseguir a prosperidade, o tesouro dos mouros, que consiste na observancia dos valores dominantes da comunidade campesiña: virilidade, traballo e moderación.

O feito de que na actualidade o Fulión estea aberto á participación de todos os membros da parroquia, indiferentemente do seu sexo e idade, ou incluso se abra a forasteiros, informa sobre a perda do significado orixinario da Festa das Fachas de Vilelos. A corrida do galo, ao igual que o medo ás bruxas, non son máis que nebulosas arrecantadas no máis profundo da memoria dalgúns dos fregueses, quen non poden evitar sorrir ou facer burla ao falar destes asuntos. Pero non todo se perdeu no Fulión de Vilelos, debido á boa disposición dos seus veciños e veciñas para revitalizar unha festa que todos consideran parte importante das súas vidas e prezada herdanza dos seus antepasados.

\section{Bibliografía}

APARICIO CASADO, B. 1999. Mouras, serpientes, tesoros y otros encantos. Mitología popular gallega. A Coruña, Edicións do Castro.

APARICIO CASADO, B. 2002. A sociedade campesiña na mitoloxía popular galega. Santiago de Compostela, USC-Serie Galicia.

ARIZAGA, A.; AYÁN, X. 2007. "Etnoarqueología del paisaje castreño, la segunda vida de los castros". En F.J. González García (coord). Los pueblos de la Galicia céltica. Madrid, pp. 445-531.

AYÁN, X (Coord.), 2002. Pasado e futuro de Castrolandín (Cuntis): unha proposta de recuperación e revalorización. Santiago de Compostela, CSIC.

BANDE RODRÍGUEZ, E. 1997. "Religiosidad, creencias y prácticas vitales del campesinado gallego", Cuadernos de Estudios Gallegos, Tomo XLIV, Fascículo 109, pp. 301-324. DOI: https://doi. org/10.3989/ceg.1997.v44.i109.225

BRAÑAS, R. 2005. "Sobre penes, risas e meigallos. Dous amuletos romanos no Castelo de San Antón", Boletín Amigos do Arqueolóxico 9, pp. 13-16.

CASTRO PÉREZ, X. 1991. "Vida cotián e mentalidades na Historia da alimentación galega: banquetes fúnebres, ánima e velorios”. En VI Xornadas de Historia de Galicia. Mentalidades colectivas e Ideoloxías. Ourense, pp. 245-57.

COCHO, F. 1990. O carnaval en Galicia. Vigo, Xerais.

CUBA, X.R., REIGOSA, A. e MIRANDA, X. 1999. Diccionario dos seres míticos galegos. Vigo, Xerais. FERNÁNDEZ DE ROTA, J.A. 1984, Antropología de un viejo paisaje gallego. Madrid, Centro de Investigaciones sociológicas.

FERRO COUSELO, X. 1952. Os petroglifos de término e as insculturas rupestres de Galicia. Ourense. FREÁN CAMPO, A. 2015, "El imaginario de la alteridad como fuente de conocimiento arqueológico e histórico. El caso del noroeste peninsular”, Gallaecia 34, pp. 249-276.

GONZÁLEZ ALCANTUD, J.A.; BUXÓ REY, M.J. (Coord.) 1997. El fuego. Mitos, ritos y realidades. (Coloquio Internacional, Granada 1995). Anthropos.

GONZÁLEZ REBOREDO, X.M. 1989. A festa de San Xoán. Vigo. Ir Indo. 
LISÓN TOLOSANA, C. 2004 (1974). Brujería, estructura social y simbolismo en Galicia. Madrid. Akal.

LLINARES GARCÍA, M. 1990. Os mouros no imaxinario popular galego. Santiago de Compostela, USC-Serie Galicia.

LLINARES GARCÍA, M. 1990a. Mouros, ánimas, demonios: El imaginario popular Gallego. Madrid, Akal.

LÓPEZ CUEVILLAS, F. e FRAGUAS FRAGUAS, A. 1955. "Los castros de la Tierra de Saviñao". En III Congreso Nacional de Arqueología. (Galicia, 1953). Zaragoza, pp. 273-348

LÓPEZ PEREIRA, X.E. 1996. Cultura, relixión e superstición na Galicia sueva. Martiño de Braga. De correctione rusticorum. A Coruña. UDC

MANDIANES, M. 1996. “O pan das ánimas”, Boletín Auriense XXVI, pp 205-12.

MARIÑO FERRO, X.R. 1984. "Bruxas: as fillas de Mani”. En Io Coloquio de Antropoloxía de Galicia. C.S.E Sargadelos, pp. 90-106

QUINTÍA, R. 2012. “Mouros e mouras. Na procura de nós mesmos". En VVAA Scrita Contemporánea. Os mouros e as mouras: máxicos enigmáticos da mitoloxía popular. pp.13-41

TABOADA CHIVITE, J. 1969. "A cencerrada en Galicia”. En J. TABOADA, Ritos y creencias gallegas. A Coruña. Sálvora, pp. 203-217.

TABOADA CHIVITE, J. 1975. "La encrucijada en el folklore de Galicia”, Boletín Auriense V, pp. 101112.

VANSINA, J. 1965. Oral Tradition. A Study in Historical Methodology. London.

VÁZQUEZ RODRÍGUEZ, J.M. 1998. “Cerimonias de véspera: os folións na Ribeira Sacra”, Boletín do Museo Provincial de Lugo 8-1, pp. 215-290.

VVAA. 2012. Scrita Contemporánea.Os mouros e as mouras: máxicos enigmáticos da mitoloxía popular. Actas das V Xornadas de Literatura de Tradición Oral. AELG. 